\title{
蛍光を利用した遺伝子発現解析 一ボンビキシン遺伝子の脳神経分泌細胞特異的発現一
}

\author{
本 賢一・吉田 郁代·Salah Eldin Abdel Salam \\ 桜井 勝 - 岩見 雅史 ${ }^{*}$
}

クローニングされた遺伝子を特徵付けるうえ で, 遺伝子発現の組織特異性や時期特異性, あ るいは転写調節機構を調べることは非常に重要 である。筆者らが研究対象としているカイコガ (Bombyx mori, 以後カイコと略)ボンビキシン (bombyxin)遺伝子は, インスリン様遺伝子であ りながら多重遺伝子族を形成しているなどイン スリン遺伝子との相違点が多く興味深い。特に 筆者らはボンビキシン遺伝子の脳神経分泌細胞 における特異的発現に注目しているが，これま でカイコではトランスジェニック体を作成する ことができず, 転写調節機構の解析がままなら ない状態であった。そこで筆者らは脳に遺伝子 を直接導入することにより, カイコボンビキシ ン遺伝子の神経分泌細胞における発現調節の解 析を行うことを試みた。本稿では GFP(Green Fluorescent Protein)レポーター遺伝子を利用 した in vitroエレクトロポレーションによる昆 虫脳への遺伝子導入法について紹介する。

\section{1.はじめに}

個体への遺伝子導入法は近年著しく発展しており, ウイルスベクターなどを用いた有用な方法が多く開 発されている。しかしこれらの方法が確立されてい るのはごく一部の生物に限られており, カイコをは じめとして多くの生物では遺伝子導入のためには物 理的方法あるいは電気的方法などで直接導入する必 要がある。エレクトロポレーションはその代表的な 遺伝子導入法であり, エレクトロポレーションは導 入時の最適条件を決定することができれば簡単な操 作で繰り返し遺伝子導入を行え, しかも導入効率が 高いという利点を持っている。この方法によって導
入された遺伝子は染色体に組み込まれることもなく 細胞内で徐々に壊されていくが, GFPのように検 出感度の良いレポーター遺伝子さえ用いれば, 一過 性の遺伝子発現を検出するには充分な感度を持って いる。

\section{2. ボンビキシン}

ボンビキシンは無脊椎動物で最初に見いだされた インスリン様分子として注目をあびた ${ }^{14)}$ が, その後 多くの研究者によりインスリンとの類似点及び相違 点が徐々に明らかにされてきた。残念ながらボンビ キシンの生理作用については糖代謝, 卵巣成熟ある いは細胞分裂への関与などが示唆されているものの まだまだ不明瞭な点が多い一方で, 遺伝子レベルで は多くの知見が得られてる。まずボンビキシンの遺 伝子構造はインスリンと全く同じで, シグナルペプ チド， B 鎖，Cペプチド， A 鎖から構成される前駆 体をコードしている5 。しかしボンビキシン遺伝子 はゲノムあたり少なくとも32コピー存在し ${ }^{11,19,21,22)}$, インスリン遺伝子が1コピー(マウスやラットなど では例外的に 2 コピー)しか存在しないのとは対照 的である。これら 32 ピーの遺伝子はその塩基配列 の相同性から $\mathrm{A} \sim \mathrm{G}$ の 7 ファミリーに分類されてお り, カイコゲノム中には, Aファミリー遺伝子は 10 コピー, Bファミリー遺伝子は 12 コピー, Cファミ リー遺伝子は 6 コピー, D, E, F, Gの各ファミ リー遺伝子はそれぞれ 1 コピーずつ存在している。 またこれらの遺伝子はゲノム中でトリプレット，ぺ ア, シングルを単位とする独特の構造様式をとり, クラスターを形成している ${ }^{11)}$ (図 1 )。

インスリンの主要産生部位は消化管(膵臓のラン ゲルハンス島 $\beta$ 細胞)であるが, ボンビキシンの主

*Ken-ichi MOTO, Ikuyo YOSHIDA, Salah Eldin ABDEL SALAM, Sho SAKURAI, Masafumi IWAMI, 金沢大学大学院自然科学研究科(广920-1192 金沢市角間町) 

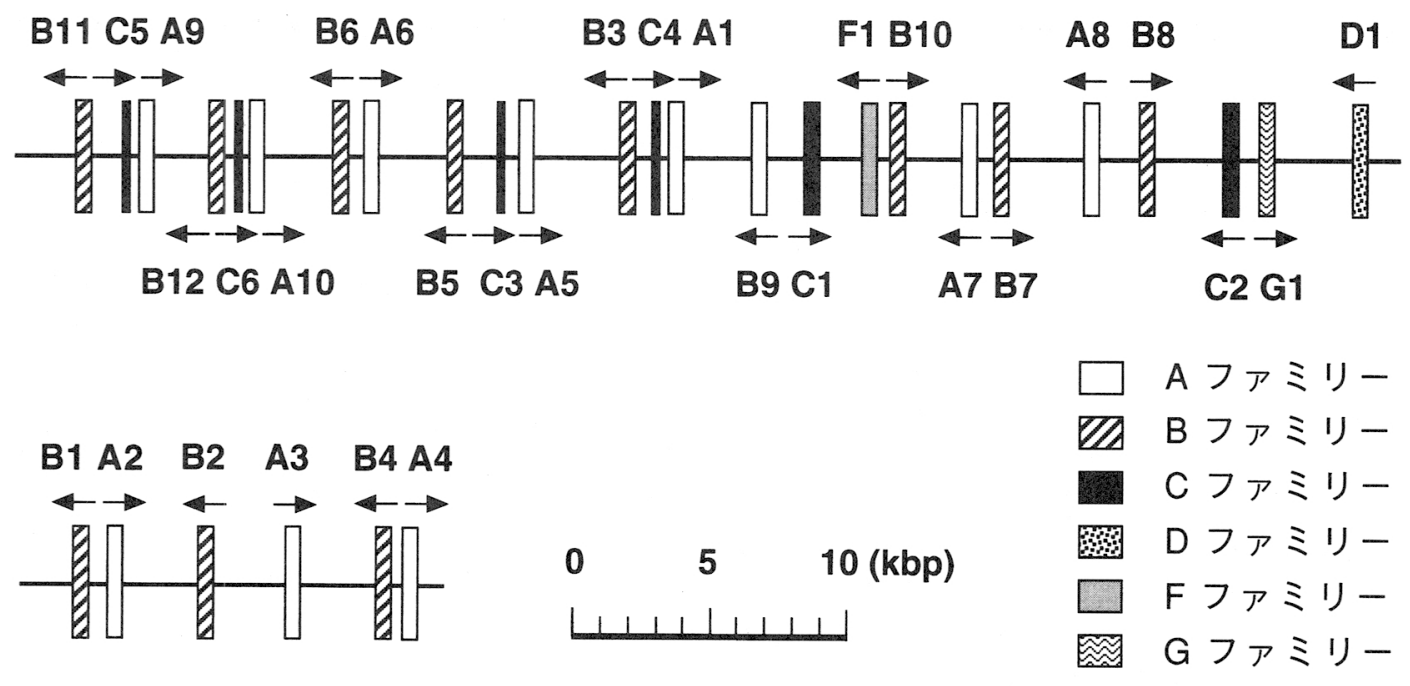

図 1 ボンビキシン遺伝子群の地図 四角はボンビキシン遺伝子の位置を, 矢印は遺伝子の転写方 向を, 英数字は遺伝子名を示している。ボンビキシン遺伝子はペア，トリプレットを基本構成単位

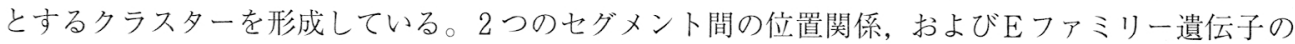
位置は現在のところ不明。 $\mathrm{kbp}$ はキロ塩基対を示している。

要産生部位は䑈であり(他の組織では微量の遺伝子 発現しか見られない( $\left.{ }^{6}\right)$, すべてのファミリー遺伝 子が脳背側中央部の 4 対(両半球で計 8 個)の神経分 泌細胞で特異的に転写されている ${ }^{19,21,22)}$ (図 2 )。ま たその転写様式は脳内の mRNAの解析結果により 次のことが明らかにされている。まずAファミリー 遺伝子ではペアを構成する遺伝子では発現が見られ るが，トリプレットを構成する遺伝子では発現が見 られない。一方 Bファミリー遺伝子では, ペア, ト リプレットといった遺伝子構成に関係なく特定の遺 伝子だけが発現している。またCファミリー遺伝子 は，ペアを構成する遺伝子では発現しているが，卜 リプレットを構成する偽遺伝子では発現が見られな ( ${ }^{7,8)}$ 。しかし現在までのところ, ボンビキシン遺 伝子の脳神経分泌細胞特異的転写調節機構は不明で, 筆者らはその解析のための実験系の確立を試みた。

\section{GFP}

GFP は北大西洋のシアトル近海に生息するオワ ンクラゲ(Aequorea victoria)体内に存在する約 27 $\mathrm{kDa}$ の緑色蛍光タンパク質である。クラゲ体内で の GFP が発光する過程は，まず別の蛍光分子であ

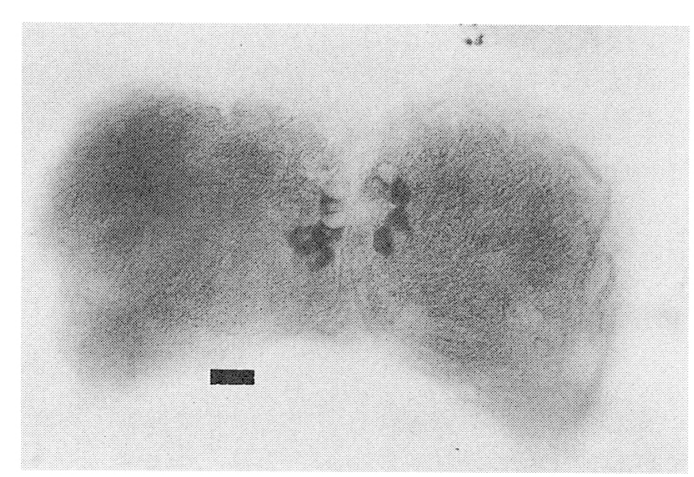

図 2 カイコ 5 令 4 日目の幼虫脳の wholemount in situ hybridizationによるボンビ キシン遺伝子発現細胞の同定 ボンビキシン遺 伝子は脳背側中央部の左右 4 対, 計 8 個の大型 の神経分泌細胞(濃い)灰色で示されている)での み特異的に発現している。図は Gファミリー 遺伝子を特異的に認識するプローブを用いた結 果であるが, $\mathrm{A} \sim \mathrm{F}$ ファミリーについても同 様の結果が得られている。スケールバーは50 $\mu \mathrm{m}$ である。 
るエクオリン内で生じた蛍光エネルギーの GFP 分 子内への転移によりの発色団を励起し, それが基底 状態に戻るときのエネルギー放出時に光として発光 するというものである。また単離した GFPでも長 波長の紫外線を照射するだけで他の補助因子などを 必要とせずに安定に発光し，さらに多くの生物種に おいて cDNA から発現させた GFP が紫外線照射 により細胞内で発光することから, 新たな生体蛍光 マーカーとして注目を集めている ${ }^{1,2,17)}$ 。GFP が生 体内マーカーとして有効である点として次のような ことがあげられる。1）蛍光による検出感度が比較 的高い[CLONTECH(http://www.clontech.com) 社から販売されている GFP 変異体である EGFP (enhanced GFP)の蛍光強度は野生型のものより 35 倍強く, 蛍光顕微鏡下で十分に観察可能である]。 2 ) 成熟分子は非常に安定なタンパク質であり ${ }^{18)}$, 例えば 4 \%パラホルムアルデヒドなどで固定しても 蛍光を検出することができる。3）比較的退色が少 ないことから長時間の観察も可能である ${ }^{16)}$ 。4) 抗 体を用いる時のような特別な固定を必要としないの で，生きた細胞で直接観察することも可能である。 つまり目的のタンパク質と融合させることにより蛍 光タグとして, 顕微鏡下でそのタンパク質の細胞内 での局在あるいは移動をリアルタイムで観察するこ とができる ${ }^{4,16) 。 ~}$

このようにGFPはレポーター遺伝子として非常 に優れている面を持つ一方で，他のレポーター遺伝 子に比べて劣っている点もある。まず GFP は翻訳 されてから実際に蛍光を発するまで，つまり成熟分 子になるまで時間を要する(野生型で $2 \sim 4$ 時間, 変異体の S65T で約30分, ただし低酸素条件下では 更に遅〈なる ${ }^{3)}$ )ので遺伝子発現時期を特定するに は不向きな場合がある。特にキイロショウジョウバ エ(Drosophila melanogaster)の胚発生のように 短時間で著しく形態変化が起こるような場合はとて も使うことはできない(細胞系譜を調べたい場合に は使える ${ }^{20)}$ のだが)。また GFP の蛍光強度はその 分子数に比例するので, 間接蛍光抗体法などに比べ 正確に定量できることが期待されるが, 前述のよう に実際に蛍光を検出できるのは成熟分子であり, 翻 訳直後の分子は検出できないという欠点がある。ま た GFP は非常に安定な分子であるために導入後時 間が経過するにつれて細胞内に蓄積される。つまり 発現量が一定であっても導入後の時間が長くなるほ ど蛍光強度が増加することになる。さらに 1 細胞あ
たりの GFP 分子数が無限に増加することはあり得 ず，ある程度時間が経過すれば飽和状態になること が予想される。以上のようなことから，GFPを用 いて遺伝子発現量を定量するためには，遺伝子導入 から蛍光の検出までの時間を固定するなどの工夫が 必要である。

最近 CLONTECH 社から d2EGFP と名付けられ た EGFPの変異体をコードするべクターが販売さ れた。EGFPの半減期は普通24時間以上であるが, この d2EGFPのそれは約 2 時間と非常に短い。つ まり, EGFPの場合は遺伝子導入後時間が経過す るにつれ蛍光強度が増加するのに対して, d2EGFP の場合は発現量が一定であればある程度蛍光強度も 一定であり，より正確な定量に適していると言える。 今後さらに半減期の短い変異体ができることも予想 され, 遺伝子発現の定量のためのマーカーとして GFP がルシフェラーゼにとって変わる日も来るの ではないかと思われる。

\section{4. エレクトロポレーションによる昆虫脳への 遺伝子導入}

現在までに細胞内への遺伝子導入法に関して様々 な方法が開発されているが, エレクトロポレーショ ンはそれらの中でも最も簡易に行える方法の一つで ある。原理はいたって簡単で, まず遺伝子を導入し たい細胞あるいは組織の周囲に適当な濃度の DNA が存在する条件下でパルスを与える。このパルスに より生じた電場により一部の細胞膜に一瞬穴が生じ, この穴を通って DNA が細胞内へと移動するという 仕組みである。真核生物の場合なら, 細胞内に入っ たDNAは何らかの機構により核内に移行し，ゲノ ム DNA と同様に転写が開始される。

エレクトロポレーションで遺伝子導入を行う上で 最も重要であり, 最も苦労するのが DNA 導入時の 諸条件の決定である。まず電極であるがこれは導入 したいサンプルに合わせて選ぶ必要がある。一般的 には in vivoでキャピラリーなどを用いて DNA を 目的の細胞付近に注入後, ニードル型, あるいはピ ンセット型などの電極を用い, 組織を電極で挟むよ うな状態でパルスを与えることにより導入する方法 と, in vitroでキュベット型あるいはディッシュ型 などの電極を用い，DNA と細胞(あるいは卵など) の混合液にパルスを与えることにより導入する方法 がある。ここで紹介したもの以外にもいろいろな夕 
イプの電極を使い分けることにより，種々な導入法 が可能である(電極は特注も可能である)。筆者らが 実際に用いている電極は， $2 \mathrm{~mm}$ ギャップのマイ クロスライド型(BTX 社，450-20BG)である。この タイプの電極はカタログには浮遊細胞への導入用と 記載されているが，カイコの脳は十分に小さいので 問題なくエレクトロポレーションを行える。またこ のタイプであれば, 調整する DNA 量が $80 \mu 1$ と少 なくてすむという利点がある。具体的には，前もっ て $20 \mu \mathrm{g} / 80 \mu 1$ になるように DNA を培養液に溶解 させておく。一般的には DNA 濃度は濃い方が導入 効率は良い(15) が，筆者らの場合にはこれよりも低濃 度の DNA 溶液でもうまくいくことがある。また導 入する DNA は環状より直鎖状の方が導入効率 ${ }^{15}$ や 翻訳効率が良いと言われている。筆者の場合は環状 のまま使用しているが，直鎖状 DNA であれば DNA 濃度はもっと低濃度でもうまくいくと思われ る。次に昆虫脳を外科的に摘出し，これらを必要な 数(筆者らの場合12個)が揃うまで適当な緩衝液中に 溜めておく(そのまま DNA 溶液に浸していくと脳 を摘出している間にDNA 溶液が蒸発し，液量が減 少する可能性がある)。必要数の脳が揃えば DNA 溶液を電極の間に流し込み，これに摘出した昆虫脳 を浸す。この時に標的細胞が電極のマイナス極側に くるように向きを整えるのがうまく遺伝子導入する ためのこつである。これは電気泳動の場合と同じで, パルスを与えた瞬間 DNA 分子が電極のマイナス極 からプラス極に移動するからであり，また浮遊した 細胞の場合と違い組織に対するエレクトロポレーショ ンでは組織のマイナス極側の数層の細胞にしか導入 されないからである。またこれらの過程で重要なこ とは, 脳の数や, DNA 溶液量などの条件を常に一 定にすることである。これらの条件が一定でなけれ ば当然再現性に問題がでてくるであろう（筆者らの 場合，全く同じタイプの電極であるにもかかわらず， 古いものから新しいものに換えただけでうまくいか なくなったことがあった。電極の抵抗などに違いが あったようである)。

次にエレクトロポレーションの条件であるが，一 般的に動物細胞は電気ショックに弱いためエレクト ロポレーターはスクウェアパルス波型のものを使用 する。それ以外にエレクトロポレーターの方で設定 する条件としては, 電圧, パルス幅, パルス回数, パルス間隔があげられる。筆者らが使用しているエ レクトロポレーター(BTX社の T820)の場合, パル
久間隔は約 1 秒間で固定されているので残りの $3 つ$ の条件を自分で設定する必要がある。とりあえず， 標的細胞で発現するような強力なプロモーターにレ ポーター遺伝子をつないだコンストラクトをコント ロールとして用い，様々な条件でエレクトロポレー ションを行ってみるのが一番手っ取り早いように思 える。電圧 $100 \sim 500 \mathrm{~V} / \mathrm{cm}$, パルス幅 $50 \sim 99 \mathrm{msec}$, パルス 1 ～回ぐらいを目安として, 発現効率が良 くかつ細胞のダメージ(細胞内のタンパク質などが 不可逆的に変性してしまうなど)が極力少なくなる ように条件を設定する ${ }^{13)}$ 。一般的に発生熱(電圧の 2 乗と負荷時間に比例し, 抵抗に反比例する)が高 いほど遺伝子導入効率が良いと言われているが，当 然細胞へのダメージも多くなり, 場合によっては細 胞そのものが死んでしまうこともあるので，このあ たりの選択が難しいところである。ちなみに筆者ら が現在カイコ脳に対して行っている条件は, 電圧 40 $\mathrm{V}$ (ギャップ $2 \mathrm{~mm}$ ), パルス幅 $50 \mathrm{msec}$, パルス 5 回 である(図 3 )。エレクトロポレーション時の温度は, 一般的には低温の方がサンプルの熱によるダメージ が少なくかつ導入効率も良いとされている。そこで, 筆者らは脳を DNA 溶液中に浸した後, エレクトロ ポレーションの直前直後の 10 分間ずつ電極ごと水上 に置くという処理を行っていた時期があったが，力 イコ脳の場合低温処理した方が蛍光顕微鏡での観察 時にバックグランドが高くなる傾向があった(理由 はわからない)ので, 現在では室温のままエレクト ロポレーションを行っている。

図 4 A はボンビキシン B12遺伝子のプロモーター と GFP 遺伝子からなるレポーター(図 3 )をエレク トロポレーションにより 5 令 3 日のカイコ脳に導入 後, 2 日間(一晚の培養でも充分である) $25^{\circ} \mathrm{C} て ゙$ 培養 液 (Grace's Insect Cell Culture Medium, GIBCO $\mathrm{BRL}, 100 \mathrm{U} / \mathrm{ml}$ ペニシリンと $100 \mu \mathrm{g} / \mathrm{ml}$ ストレプ トマイシンを含む)中において in vitro 培養して GFP を発現させ, これを蛍光顕微鏡 (OLYMPUS, BX50, ミラーユニットは U-MNIBA を使用)で観 察した結果である。この図から, ボンビキシン遺伝 子のプロモーターを持つレポーター遺伝子が脳中央 部の大型の神経分泌細胞で特異的に発現しているの がわかる。ただしこの結果からだけでは，レポーター が偶然にボンビキシン産生細胞だけに導入されたと いう可能性を否定できない。そこでエレクトロポレー ションでは DNA はランダムに細胞に導入されるこ とを証明すべく，すべての細胞で発現すると考えら 


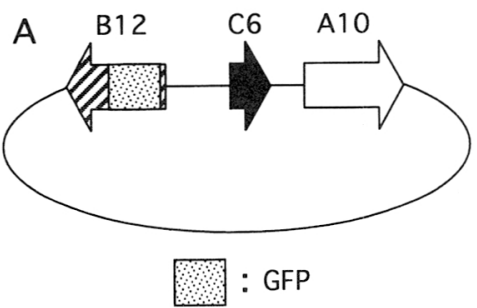

ボンビキシン B12 遺伝子プロモーター・ GFPレポーター遺伝子

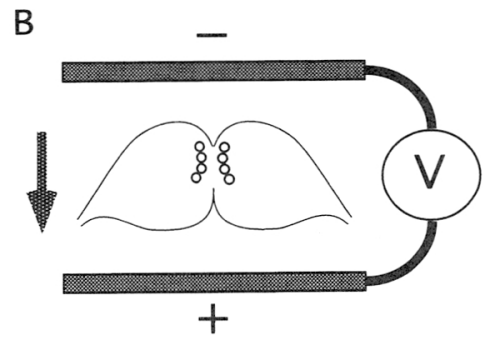

$40 \mathrm{~V}, 50 \mathrm{msec}, 5$ パルス

図3レポーター 遺伝子 の構造とエレクトロポレー ションの模式図 A : ボン ビキシン B12遺伝子とその 周辺領域を含むプラスミド をテンプレートとし，B12 遺伝子内部の一部を欠失さ せるように PCR を行い， この PCR 産物に GFP 遺 伝子コード領域断片を連結 させた。B：エレクトロポ レーションの模式図。矢印は DNA 分子の移動方向を示す。ボンビキシン B 12 遺伝子が導入されれば，図 中の脳中央部の 4 対の神経分泌細胞のいずれかが緑色の蛍光(図では白色で示されている)を発するはずである。
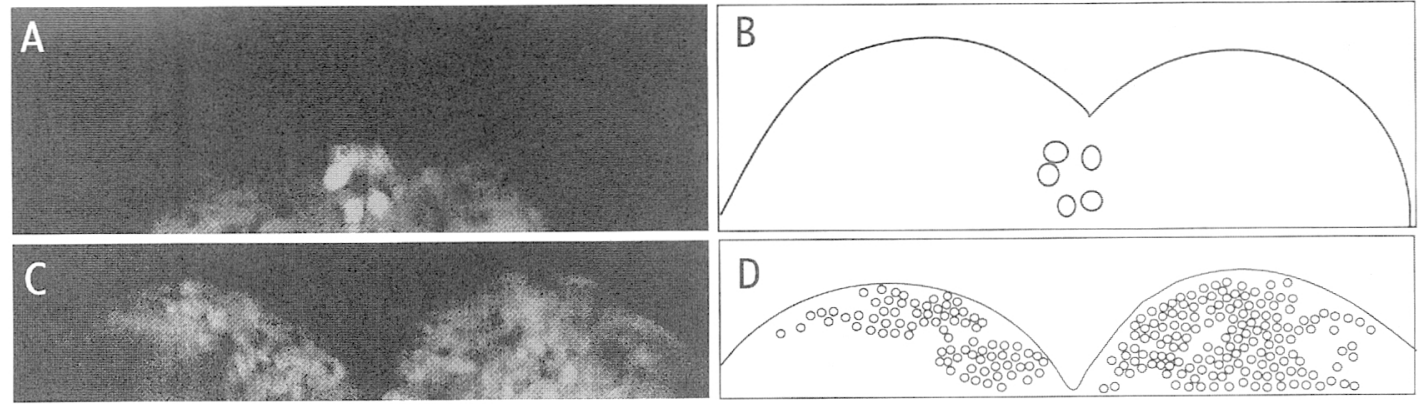

$\mathrm{E}$

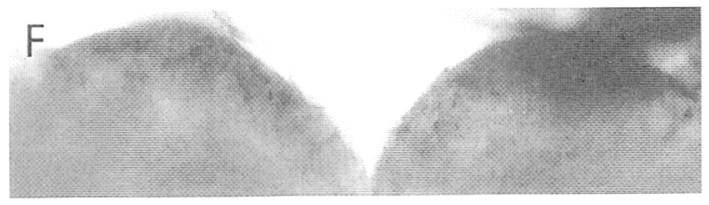

図 4 カイコ脳神経細胞での GFP の発現 A〜Dは蛍光顕微鏡を用いて GFP の蛍光を観察した 結果と模式図を，Eと F は抗 GFP抗体を用いて免疫組織化学的にGFPを検出した結果である。 蛍光像は白色で, 免疫組織像は黒色で示される。A：ボンビキシン B12遺伝子プロモーター・GFP レポーター遺伝子を導入した場合。B：Aの模式図。C：アクチンA4遺伝子プロモーター・GFP レポーター遺伝子を導入した場合。脳上層部の多くの細胞でGFPの発現が見られる。D：Cの模 式図。E：ボンビキシン B12遺伝子プロモーター・GFPレポーター遺伝子を導入した場合。ボン ビキシン産生細胞でのみ染色が見られる。F：アクチン A4遺伝子プロモーター・GFPレポーター 遺伝子を導入した場合。上層部の多くの細胞で GFPの発現が見られる。

れるアクチン $\mathrm{A} 4$ 遺伝子プロモーター ${ }^{12)}$ と GFP 遺 伝子からなるレポーターを作成し，これをボンビキ シン遺伝子のレポーターの場合と同様にエレクトロ ポレーションを行った。この場合, 脳上層部に位置 する多数の細胞が蛍光を発しており(図4 C), レポー
ター遺伝子がこれら不特定多数の細胞で発現してい ることがわかる(前にも述べたが，エレクトロポレー ションの場合 DNA は脳の一側面の表面付近の細胞 にしか導入されない)。このようにDNA はエレク トロポレーションにより組織のマイナス電極側の細 
胞にランダムに導入される。一方ボンビキシン遺伝 子のレポーターの場合も同様にランダムに導入され ているはずであるが, 実際にレポーターが発現して いるのは 4 対のボンビキシン産生細胞のいずれかで ある。よってボンビキシン遺伝子プロモータ一領域 にはボンビキシン産生細胞での特異的発現に関与す るエレメントが存在すると言える。

以上, エレクトロポレーションによる遺伝子導入 および蛍光顕微鏡による遺伝子発現解析について述 ベた。エレクトロポレーションの優れているところ は誰にでも(筆者らにでも)簡単に遺伝子導入が行え ることであるが, 幾つか問題点もあるのでここで触 れたいと思う。

1) GFPのように蛍光により遺伝子発現を検出 する場合, 細胞のダメージが激しいとバックグラン ドが高くなる傾向がある。これを防ぐためにはなる べく発生熱が低くなるような条件を設定しなければ ならない。筆者らの場合においてもまだまだ改善の 余地があると考えている。

2) 1 ) で述べたようにバックグランドがどうし ても高くなり，作成したコンストラクトが本当に GFP を発現しているかどうか見分けにくいことが ある。ここで言いたいことは，せっかく作成したコ ンストラクトがうまくGFPを発現しない(転写に 必要なエレメントを欠いているなど), あるいは発 現していても融合タンパク質の場合では蛍光強度が 弱いことがある(10)ということである。GFP のシグ ナルが検出できなければ, 発生熱のより高い条件で エレクトロポレーションを行う必要があるが, 前述 のようにそのような条件ではバックグランドも高く なりがちである。幸い抗 GFP 抗体が CLONTECH 社から販売されているので, GFP のシグナルが検 出しにくいようであれば免疫組織化学的に検出して みると良い(図 $4 \mathrm{EF}$ )。万一それでも検出できない ようであれば, コンストラクトを少し変えて作成し 直した方が成功への近道であると思われる(ベクター に組み込む上流配列部分を変える。あるいは遺伝子 の下流領域も組み込むなど)。またもし免疫組織化 学的に検出できる場合は, バックグランドが低くな るようにエレクトロポレーションの条件あるいはそ の後の培養条件などを再検討すべきであろう。

\section{5.おわりに}

昆虫の脳は発生・成長を最上位で支配する高次機
能器官でありながら，それを構成する細胞数はわず か数万であり, 高等動物のそれが数億から数十億で あるのにくらべてかなり少ない。もちろん昆虫には 感情などのような高度な神経機能はないが, 様々な 情報を受け入れ処理する入力系と行動や分泌を調節 する出力系は持ち合わせている。つまり脳における これらの機能に関する研究材料として昆虫の脳は非 常に適していると言えるであろう。筆者らが研究の 対象としているボンビキシンは, カイコの脳神経分 泌細胞で産生・分泌される神経ペプチドの一つであ る。幸い筆者らの研究室ではボンビキシン遺伝子に 関する多くの知見をすでに得ており, 今後脳神経分 泌細胞における遺伝子発現調節機構を解析するに当 たり充分な情報を蓄積している。しかし多くの生物 にも言えることであるが, カイコの場合トランスジェ ニック体の作成法は未だに確立されていない。それ ゆえ個体への遺伝子導入には, 本稿で紹介したよう なエレクトロポレーションなどのように組織へ直接 導入するような方法が必要であった。

エレクトロポレーション法は簡易で非常に導入効 率の高い遺伝子導入法であるが, 今のところその利 用目的の多くは培養細胞への導入であり, 組織への 導入に関して参考となるような文献はまだ少ない。 またそのような文献が手に入ったとしても, 生物種 やターゲットとなる組織あるいはその組織中の細胞 が異なれば, 当然導入時の最適条件などが異なって くるため, 全く同じ条件で行うというわけにはいか ない。つまり本文でも述べたように, 適当なプロモー ターを持ったレポーターを用いて様々な条件でエレ クトロポレーションを行うことにより, 最も良いと 思われる条件を見つける必要がある。この作業は非 常に地味で時間もかかるが, その後の研究成果を大 きく左右する筈であり念入りに行うべきである。ま た目的によっては導入効率・生存率・再現性などの 優先順位が異なるので, これらも考虑に入れて最適 条件を決める必要がある。つまり組織中の多少奥まっ たところにある細胞がターゲットである場合, 生存 率にこだわれば導入効率は低くなるはずであり, 多 少生存率が低くても発生熱が高くなるような条件を 選択した方が良いかもしれない。また筆者らのよう に将来的に GFP の蛍光強度によってその遺伝子の 発現強度を検証しようとする場合には, 多少導入効 率が低くなっても細胞のダメージがより少なくなる ような条件, つまり発熱量を抑えるような条件を選 択すべきであろう。 
今回紹介した実験系において，幸いにも筆者らは ボンビキシン産生細胞におけるレポーター遺伝子の 細胞特異的な発現を確認する事ができた。しかし蛍 光によりレポーター遺伝子の発現を確認する際にま だまだバックグランドが高く, 蛍光強度により発現 度を求めようとするには納得のいかない状態である が, 少なくとも遺伝子発現の有無を確認するうえで は優れた実験系である。特にボンビキシン遺伝子は 多重遺伝子族であるが故に, すべての遺伝子につい て in situ hybridizationのような比較的簡単な方 法で遺伝子の発現を確認するという訳にはいかない (in situ hybridization ではファミリー間での遺伝 子発現の有無を確認できても, 同一ファミリー内で 各遺伝子の発現の有無を確認することはできない)。 そのため各々の遺伝子についてその発現の有無を厳 密に決定するにはかなりの労力が必要であったが, この実験系により発生中のどのステージの脳に対し ても，32コピーのボンビキシン遺伝子すべてについ てその発現の有無を比較的容易に確認することが可 能となった。しかし筆者らの本来の目的はボンビキ シン遺伝子の細胞特異的な転写調節にかかわるエレ メントを見い出すことであり，そのためには GFP のより正確な蛍光強度を知る必要がある。今後エレ クトロポレーションあるいはその後の培養の条件も 含めて, バックグランドが減少するように実験系を 改善していく予定である。

本稿ではエレクトロポレーションを用いた昆虫脳 への遺伝子導入法について述べたが, 筆者らの研究 室ではマイクロインジェクションを用いても同様の 試みを行っている。マイクロインジェクションはエ レクトロポレーションに比べ技術的に非常に難しい が, ある程度の経験を積みかつ導入時の最適条件を 決定することができれば, 繰り返し高い導入効率で 遺伝子導入が可能である。また筆者らの経験上エレ クトロポレーションに比べて細胞のダメージが少な いため, 蛍光顕微鏡による観察時にバックグランド が非常に低いという利点を持っている。

\section{謝辞}

本研究は, 文部省科学研究費補助金特定領域研究 「昆虫の変態・休眠の分子機構」ならびに加藤記念バ イオサイエンス振興財団の支援により行われました。

\section{文 献}

1 ) Chalfie, M., Tu, Y., Euskirchen, G., Ward, W.W., \& Prasher, D.C.: Science $263:$ 802-805 (1994)

2 ) 舟橋淳一 : 細胞工学 16 : 1666-1675 (1997)

3 ) Heim, R., Prasher, D.C., \& Tsien, R.Y.: Proc. Natl. Acad. Sci. USA 91: 12501-12504 (1994)

4 ) Htun, H., Barsony, J., Renyi, I., Gould, D. L., \& Hager, G.L.: Proc. Natl. Acad. Sci. USA 93 : 4845-4850 (1996)

5 ) Iwami, M., Kawakami, A., Ishizaki, H., Takahashi, S.Y., $\quad$ Adachi, T., $\quad$ Suzuki, Y., Nagasawa, H. \& Suzuki, A.: Dev. Growth Differ. $31: 31-37$ (1989)

6 ) Iwami, M., Tanaka, A., Hano, N., \& Sakurai, S.: Experientia 52 : 882-887 (1996)

7 ) 岩見雅史 : 生化学 $70: 305-308$ (1998)

8 ) 岩見雅史, 本 賢一：化学と生物 $36: 8-10$ (1998)

9 ) Kawakami, A., Iwami, M., Nagasawa, H., Suzuki, A., \& Ishizaki, H.: Proc. Natl. Acad. Sci. USA. 86 : 6843-6847 (1989)

10）木俣行雄, 河野憲二 : 実験医学 $15: 563-567$ (1997)

11) Kondo, H., Ino, M., Suzuki, A., Ishizaki, H. \& Iwami, M.: J. Mol. Biol. 259 : 926-937 (1996)

12) Mange, A., Couble, P. \& Prudhomme, J. C.: Gene 183 : 191-199 (1996)

13）村松達夫, 朴熙万：実験医学 $15: 265-268$ (1997)

14) Nagasawa, H., Kataoka, H., Isogai, A., Tamura, S., Suzuki, A., Ishizaki, H., Mizoguchi, A., Fujiwara, Y. \& Suzuki, A.: Science 226 : 1344-1345 (1984)

15) Neumann, E., Schaefer-Ridder, M., Wang, Y., \& Hofschneider, P.H.: EMBO J. 1 : 841845 (1982)

16) Ogawa, H., Inouye, S., Tsuji, F.I., Yasuda, K., \& Umesono, K.: Proc. Natl. Acad. Sci. USA 92 : 11899-11903 (1995)

17）小川英知, 井上 敏, Tsuji, F.I., 安田國雄, 
梅園和彦 : 実験医学 $14: 495-501$ (1996)

18) Perozzo, M.A., Ward, K.B., Thompson, R. B., \& Ward, W.W.: J. Biol. Chem. 263 : 77137716 (1988)

19) Tsuzuki, S., Masuta, T., Furuno, M., Sakurai, S. \& Iwami, M.: Comp. Biochem. Physiol. 117B : 409-416 (1997)

20) Yeh, E., Gustafson, K., \& Boulianne, G.L.:
Proc. Natl. Acad. Sci. USA $92: 7036-7040$ (1995)

21) Yoshida, I., Tsuzuki, S., Abdel Salam, S. E., Ino, M., Korayem, A., Sakurai, S. \& Iwami, M.: Zool. Sci. 14 : 615-622 (1997)

22) Yoshida, I., Moto, K., Sakurai, S., \& Iwami, M.: Dev. Genes Evol. $208:$ 407-410 (1998) 